\title{
Bingkai Kehidupan Janda Meneropong Dari Kacamata Dramaturgi
}

\author{
SANTI DELLIANA \\ ${ }^{1}$ Ilmu Komunikasi, Institut Teknologi dan Bisnis Kalbis \\ Email anastasia.santi@kalbis.ac.id | Telp. 081317321868
}

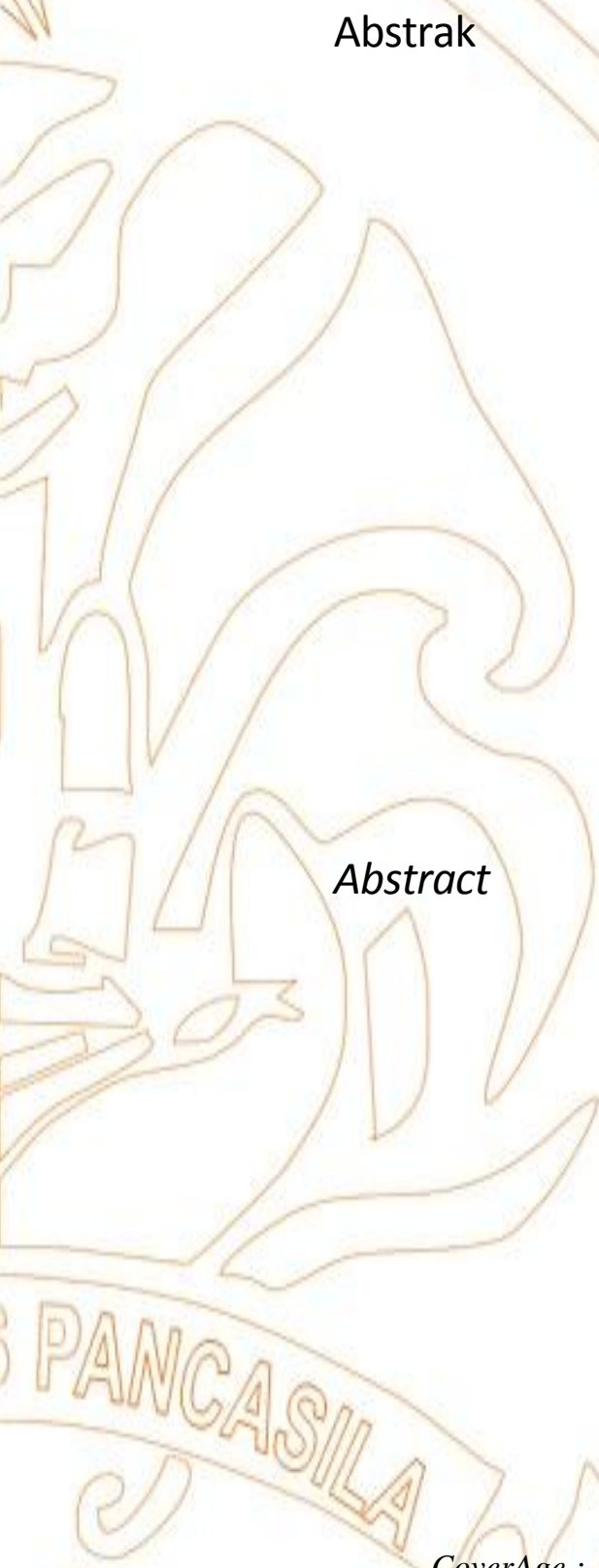

Journal of Strategic

Communication

Vol. 11,No. 2, Hal. 109-121

Maret 2021

Fakultas Ilmu Komunikasi, Universitas Pancasila
Perilaku seksual legal dilakukan dalam ikatan perkawinan. Namun perilaku seksual di luar nikah oleh janda juga menarik untuk diteliti. Karena sebagai manusia biasa, hasrat seksual tetap ada meski tidak terikat dalam ikatan perkawinan. Pertanyaan penelitian ini adalah bagaimana bingkai kehidupan seorang janda dilihat dari perspektif dramaturgi. Peneliti berusaha menemukan bahwa para janda yang berpartisipasi dalam penelitian ini, melakukan hubungan seksual di luar nikah, juga memainkan peran depan dan belakang dalam kehidupan komunitas. Pendekatan yang digunakan adalah kualitatif analitik dengan teknik pengumpulan data observasi dan wawancara dengan tiga informan. Temuan studi ini menunjukkan bahwa saat ini, informan tampaknya memiliki detail dalam bermain peran (1). Informan muncul dalam keluarga dan hubungan sosialnya sebagai perempuan yang baik dan berpendidikan, dengan mengedepankan nilai-nilai agama. Informan tampak lebih terhormat dan berpendidikan. (2). Informan tidak mengisolasi diri dari publik. Mereka memiliki banyak pasangan, tetapi mereka tetap menyendiri untuk berbagi perilaku seksual mereka. (3). Perasaan informan perlu lebih dikendalikan secara sosial dan untuk menciptakan pengalaman interaksi sosial asosiatif. (4). Ada dunia ketiga / dunia luar untuk menyaksikan aktor menjaga rahasia ini. (5). Perbedaan posisi informan dan perasaan menyesal dan berdosa terhadap Tuhan, keluarga, dan teman.

Kata kunci : Dramaturgi, janda, perilaku seksual

Legal sexual behavior is carry out in a marriage bond. However, sexual behavior outside of marriage by widows is also interesting to study. Because as a normal human being, sexual desire is still there even though marriage is not bound. This study's question is how the frame of a widow's life is view from a dramaturgy perspective. The researcher attempted to find that the widows who participated in this study, engaging in sexual intercourse outside of marriage, also played front and back roles in community life. The approach used is qualitative analytic with observation data collection techniques and interviews with three informants. This study's findings indicate that currently, informants appear to have the following details in role-playing (1). Informants appear in their families and social relations to be good and educated women, emphasizing religious values. Informants seem more respectable and educated. (2). Informants do not isolate themselves from the public. They have many partners, but they remain aloof to share their sexual behavior. (3). Informants' feelings need to be more controlled socially and to create experiences of associative social interaction. (4). There is a third world / outside world to witness the actor keeping this secret. (5). Differences in informants' position and feelings of regret and sin against God, family, and friends.

Keywords : Dramaturgy, widow, and sexual behavior 


\section{PENDAHULUAN}

Sebagian orang menganggap pernikahan adalah hal yang menyenangkan dan sederhana. Namun ternyata tidak seperti yang dibayangkan. Ada hal mendasar yang harus diperhatikan dalam mempersiapkan diri sebelum menikah yakni kematangan baik dalam fisik, psikologis maupun emosional. Sebelum memutuskan untuk menikah, aspek penting yang harus diperhatikan adalah kedewasaan diri, baik secara intelektual maupun finansial. Alasan kematangan dan kedewasaan inilah yang menuntut agar pernikahan tidak dilaksanakan secara dini sehingga angka pasangan janda dan lelaki muda semakin berkurang.

Pernikahan yang didambakan oleh kebanyakan orang adalah menikah sekali seumur hidup dan awet. Namun tidak dipungkiri, pernikahan harus berakhir karena berbagai situasi yang terjadi. Berbagai alasan yang menyebabkan semua pernikahan harus berakhir, baik pasangan harus menghadap khalik terlebih dahulu, maupun tidak merasakan kecocokan antara satu sama lain dan berakhir pada perceraian. Sebuah konsep yang melekat pada diri seseorang dan belum tentu benar adanya disebut dengan stereotip. Sebagai contoh, cerewet identik dengan perempuan, maka laki-laki tidak boleh cerewet atau banyak bicara. Permainan bola hanya dimainkan oleh laki-laki, maka perempuan tidak boleh bermain bola. Konsep inilah yang melekat pada masyarakat tentang bagaimana laki-laki dan perempuan seharusnya bersikap. Perempuan juga seringkali menjadi objek utama konstruksi realitas media massa dalam perkembangan konstruksi perempuan yang sesungguhnya (Putranto \& Delliana, 2019, p. 42).

Berakhirnya pernikahan akan meninggalkan status yang dikenal oleh masyarakat. Status itu disematkan kepada wanita yang akan disebut janda dan laki-laki yang akan disebut duda. Dalam Kamus Besar Bahasa Indonesia, janda artinya seorang wanita yang tidak memiliki suami, atau karena suaminya meninggal. Janda bukanlah akhir dari segalanya. Kebanyakan orang yang menyandang status janda, ada yang memutuskan untuk menikah kembali atau bahagia dengan statusnya sebagai seorang janda sampai akhir hayat. Seorang janda juga berhak mendapat hak kebahagiaan hidup seperti individu lain. Bagi janda yang memutuskan untuk menikah kembali, biasanya berorientasi bahwa mencari pasangan hidup karena mereka sadar dalam hidup memerlukan sosok pendamping, baik sebagai teman bercerita, bertukar pikiran, maupun tempat berkeluh kesah. Pernikahan pada seorang janda tentu bukanlah hal yang mudah, walaupun mereka sudah memiliki pengalaman sebelumnya. Ada pula yang memutuskan untuk menikah dengan pria yang lebih muda, namun dalam budaya timur Indonesia, pilihan hidup seperti itu sering dihakimi oleh masyarakat.

Permasalahan penting dalam kehidupan janda adalah waktu. Kemampuan setiap orang dalam beradaptasi berbeda-beda di sebuah lingkungan baru. Sama halnya pada pasangan janda dan lelaki muda, mereka membutuhkan waktu untuk mengenal pribadi, keluarga, anak-anak dari pernikahan sebelumnya, dan gaya hidup masingmasing pihak. Waktu dibutuhkan untuk mengamati cara berinteraksi calon pasangan dengan keluarga, teman-teman, dan bagaimana menghabiskan waktu luang. Semua hal itu memerlukan waktu yang cukup untuk memahami kehidupan yang akan dijalani. Atas dasar hal waktu, ada juga janda yang akhirnya memutuskan untuk tidak menikah kembali dan menjalani kehidupan sebagai seorang single parent. Selain waktu, agar dapat terjalin interaksi dan aktivitas dengan lancar maka diperlukan kemampuan komunikasi yang baik dan efektif antar individu (Paramithasari \& Kartika, 2017, p. 2).

Menarik sekali membicarakan seks, apalagi dalam masyarakat yang sarat akan nilai-nilai ketimuran yang didominasi oleh ajaran agama dan budaya. Dengan kata lain, tanpa memikirkan konteks budaya dan maknanya, mustahil untuk memikirkan komunikasi (Utami, 2018, p. 40). Perilaku atau nilai-nilai seksual yang berkaitan dengan seks diatur secara normatif dalam masyarakat ini. Konsep seks normatif merupakan nilai-nilai yang telah dilembagakan dalam kehidupan masyarakat, dan konsep ini dipandang sebagai perlakuan terhadap jenis kelaminnya oleh komunitas etnis (Bungin, 2003, p. 92). Walau secara normatif seks dinyatakan tabu, interaksi seksual pada pasangan janda dan lelaki muda dilakukan secara tidak tetap atau cenderung tidak setia kepada pasangannya. Mereka tidak sekedar ciuman, pelukan, tetapi hubungan seksual di luar nikah telah tercapai melalui perilaku seksual yang dimaksudkan (Salisa, 2010, p. 66). Perilaku seksual para janda telah mengalami perubahan dan mereka berkenan menceritakan. Mereka merasakan perlu adanya kesetaraan seks. Hal ini 
terjadi karena adanya pergeseran perspektif pada perilaku seksual janda.

Janda adalah orang yang sudah tidak menikah lagi, tetapi kebutuhan biologisnya harus dipenuhi. Aktivitas seksual ini berlangsung tanpa ikatan perkawinan formal. Janda memiliki pemahaman dan kebutuhan untuk dapat menempatkan diri dalam konteks sosial untuk membuat mereka merasa nyaman dan menyembunyikan situasi dari keluarga, kelompok sebaya, serta struktur sosial. Teori yang digunakan dalam penelitian ini adalah teori dramaturgi Erving Goffman, sebuah metafora dramatis yang digunakan oleh salah satu sosiolog terkenal di abad ke-20 untuk menjelaskan bagaimana komunikator menampilkan diri (Estriana \& Wahid, 2019, p. 72). Diri adalah pengaruh dramatis yang muncul dari suasana yang dihadirkan. Menurut Goffman, seseorang biasanya mencoba menampilkan dirinya di depan umum citra idealis terbaik sehingga merasa harus menyembunyikan sesuatu dari tindakannya, sehingga dapat mempertahankan kesan yang diinginkannya sesuai dengan harapan dan prinsip yang mereka rencanakan, digunakan dalam kehidupan komunitas mereka. Goffman membahas jenis tindakan interaksi yang kita lakukan setiap hari, khususnya untuk menggambarkan kepribadian seseorang dalam tampilan dramatis dengan cara yang sama seperti seorang aktor. Mengacu pada persamaan hak, artinya ada pertunjukan yang ditampilkan. Goffman berbicara tentang pertunjukan sosiologis. Kinerja dalam artian masyarakat yang memberikan kesan baik terhadap pencapaian tujuan. Tujuannya agar publik bisa memanipulasi. Jika seorang pemain berhasil, penonton dapat melihat aktor tersebut dari perspektif yang dibawakan oleh aktor tersebut, dan lebih mudah bagi aktor untuk membuat penonton memenuhi maksud serial tersebut.

Berdasarkan masalah yang telah diuraikan maka bagaimana bingkai kehidupan janda yang diteropong dari kacamata dramaturgi. Penelitian ini bertujuan untuk menganalisis bingkai kehidupan janda yang diteropong dari kacamata dramaturgi.

\section{TINJAUAN PUSTAKA}

\section{Teori Dramaturgi}

Hidup itu setara dengan film. Setiap individu memainkan karakter yang berinteraksi dengan berbagai cara dalam kehidupan. Anda hanya bisa melihat kehadiran apa yang dihadirkan manusia lain dalam proses interaksi sosial. Yang coba dijelaskan oleh teori dramaturgi adalah kemunculan diri manusia saat berinteraksi dalam tahapan kehidupan yang disertai dengan penggunaan berbagai tanda untuk mencapai tujuan tertentu. Ini seperti panggung atau teater menurut teori dramaturgi yang mendukung kehidupan manusia. Apa dan bagaimana teori dramaturgi akan diuraikan secara singkat di bawah ini.

Teori dramaturgi adalah pengaruh terhadap fenomena, atau respon terhadap konflik sosial dan rasial yang semakin meningkat, birokrasi, dan dampak represif industrialisasi. Teori sebelumnya menekankan pada kelompok atau struktur sosial, sedangkan teori Goffman menekankan sosiologi individu sebagai analisis, khususnya dalam hal interaksi tatap muka. Sehingga trend melahirkan dramaturgi (Hersavira, 2019, p. 31). Melalui bahasa dan interaksi mikroanalitik, teori drama mengeksplorasi pembentukan diri sosial, relasi, dan realitas sosial. Teori dramaturgi Erving Goffman mengasumsikan bahwa identitas diperlihatkan kepada audiens pada suatu peristiwa dan suatu tempat.

Pengertian pertunjukan dan hubungan antara aktor dan penonton pada waktu dan tempat tertentu merupakan aspek penting dari teori dramaturgi dalam konteks komunikasi. Melalui manajemen pertunjukan, aktor perlu mengontrol drama mereka sendiri untuk membangkitkan reaksi. Esensi yang popular dalam teori dramaturgi, yaitu konsep panggung depan dan belakang. Konsep ini terhubung bersama tetapi dua bidang yang berbeda dalam interaksi tatap muka. Teori ini juga mengangkat tentang kepercayaan menjadi bagian terpenting dalam pertunjukkan. Penonton diminta untuk mempercayai karakter yang dimunculkan beserta atribut-atribut pendukung. Penonton diyakinkan bahwa karakter tersebut tulus dan membawa kesan sesuai realitas yang ada pada diri aktor (Goffman, 1959, p. 17). Sedikit penjelasan tentang Panggung Depan dan Belakang: 


\section{A. Panggung Depan atau Front Stage}

Ketika kita berkomunikasi dengan orang lain, kita menilai individu itu berdasarkan petunjuk berbeda yang diberikan orang lain dan sebaliknya. Kami memperlakukan orang lain atau sebaliknya atas dasar penilaian itu. Dengan kata lain, kita akan dengan sengaja menampilkan diri kita seperti yang kita inginkan saat berinteraksi dengan orang lain. Kemudian, apa yang mungkin kita gunakan untuk menampilkan diri kita kepada orang lain dikenal sebagai front yang terdiri dari panggung, tampilan dan gaya perilaku.

\section{B. Panggung Belakang atau Back Stage}

Erving Goffman mengatakan bahwa konteksnya adalah di mana artis dapat bersantai, di mana dia dapat melepaskan semua peralatan yang digunakan untuk menunjukkan dirinya. Setelah pertunjukan selesai, individu tersebut datang ke belakang panggung dan dibebaskan dari ekspresi, bebas dari berbagai aksi yang dilakukan di atas panggung. Tidak semua orang akan puas dengan semua tindakannya kecuali dirinya sendiri. Backstage adalah tempat artis hadir, tapi tanpa melihat penontonnya. Juga di belakang panggung, tanpa takut merusak penampilannya, seorang seniman bisa saja keluar dari karakter aslinya.

Proses penelitian ini didirikan atas dasar perdebatan tentang fenomena perempuan yang masih berstatus janda setelah bercerai. Meski sudah menjanda, namun wanita ini nyaman menjalani hidupnya. Fenomena ini memiliki pesona dan daya tarik tersendiri di masyarakat. Perempuan yang berstatus janda di satu sisi dianggap sebagai masalah, namun di sisi lain, kenyataan itu bisa ditemukan di mana-mana. Gagasan tersebut muncul dari kenyataan bahwa perempuan berstatus janda sebagai pribadi yang nyata dan eksis dalam masyarakat harus membaca kembali karya sastra yang berstigma negatif. Peneliti mencoba dalam perspektif perempuan, individu sebagai topik penelitian, untuk memahami realitas ini. Peneliti melakukan wawancara dan penelitian yang direkam dan didaftarkan sebagai laporan penemuan data.

\section{METODE}

Pendekatan fenomenologi digunakan dalam penelitian ini. Konsep, konteks atau kerangka di mana bahasa dan perilaku dipahami merupakan istilah yang diambil dari Bateson dan teori interaksi. Berdasarkan kerangka sejarahnya, kerangka tersebut dirancang untuk menjelaskan bagaimana setiap orang yang berinteraksi menyajikan pesan metacommunication, yaitu informasi tambahan tentang bahasa dan perilaku selama suatu peristiwa.

Penelitian ini menggunakan metode penelitian kualitatif. Peneliti sendiri, sebagai human instrument, adalah instrumen atau alat penelitian. Berfungsi untuk menentukan fokus penelitian, memilih informan sebagai sumber data, mengumpulkan data, menganalisis data, menginterpretasikan data, dan membuat kesimpulan tentang hasil (Sugiyono, 2019, p. 221).

Waktu penelitian adalah Mei 2019 - Juli 2020. Lokasi penelitian di wilayah Jakarta.

Informan penelitian dibutuhkan sebagai sumber penelitian dalam penelitian kualitatif. Penentuan informan yang tepat akan mempengaruhi kebenaran hasil penelitian. Dalam penelitian ini terdapat informan dari akar rumput dan informan kunci (Koentjaraningrat, 1991, p. 130). Menurut Koentjaraningrat, informan dasar adalah orang yang dapat memberikan informasi umum dan menunjuk orang lain sebagai informan kunci yang dapat memberikan informasi yang lebih detail. Dalam penelitian ini subjek penelitian adalah wanita yang berstatus janda.

Informan sangat penting dalam penelitian kualitatif. Seperti yang tersirat dari namanya, ini memberi para peneliti informasi. Tidak ada informasi tanpa informan dan tidak akan ada studi tanpa informasi yang jelas. Orang yang membuat laporan tanpa informan berarti menulis fiksi seperti cerita pendek atau novel, atau paling banter, membuat laporan faktual, yang sebenarnya hanyalah sebuah cerita autobiografi tentang dirinya sendiri.

Informan juga mendefinisikan realitas sosial. Tidak seperti penelitian kuantitatif, tidak ada realitas sosial tunggal dan universal dalam penelitian kualitatif. Tugas peneliti adalah untuk mengeksplorasi dan mengungkap realitas terfragmentasi yang unik ini - sebuah upaya yang hanya dapat dilakukan oleh peneliti jika ia mampu menahan (mengandung) prasangka yang muncul dari sudut pandangnya.

Sebagaimana ditulis Mulyana (2006, p. 147) dengan prinsip-prinsip paradigma subjektif tentang sifat manusia (masing-masing peserta 
komunikasi adalah aktor/komunikator). Oleh sebab itu dalam penelitian, ini peneliti menyebut informan dengan istilah komunikator. Informan penelitian adalah orang-orang yang biasa memberikan informasi tentang keadaan penelitian dan latar belakang kondisi (Moleong, 2008, p. 97). Informan adalah orang yang benar-benar mengetahui cara mempelajari masalah. Studi ini melibatkan informan dasar dan informan kunci (key informan) (Koentjaraningrat, 1991, p. 130).

Berikut ini adalah data identitas informan penelitian yang dapat mendukung kelancaran penelitian ini, karena dengan latar belakang umur, Pendidikan dan pekerjaan yang diketahui oleh peneliti, maka tentunya proses pengambilan data penelitian akan lebih mudah untuk menentukan teknik pengambilan datanya.

Dengan menerapkan teknik pengambilan sampel yang cermat (purposive sampling) yaitu teknik pengambilan sampel sumber data dengan pertimbangan tertentu. Pertimbangan pilihan sampel tertentu yang dibuat oleh peneliti adalah wanita yang telah menyandang status janda dengan surat resmi akta cerai dan melakukan hubungan seksual dengan lawan jenis tanpa ikatan pernikahan.

Sumber data dalam penelitian ini adalah topik untuk memperoleh data. Ada dua jenis sumber data, yaitu sumber data primer dan sekunder. Sumber data yang diperoleh langsung dari lapangan adalah sumber data primer (Nugraha, 2005, p. 60).

1. Wawancara; tujuan wawancara ini adalah untuk menemukan data tentang signifikansi terkoordinasi seks antara janda dan pria yang lebih muda.

2. Dokumentasi dari pasangan janda dan remaja putra serta data lain yang berkaitan dengan permasalahan peneliti untuk dijadikan bahan rujukan bagi peneliti.

Penulis menggunakan metode analisis induktif dengan mengembangkan teori dari data dalam analisis ini (Mulyana, 2006, p. 156). Analisis didasarkan pada kasus-kasus tertentu berdasarkan pengalaman nyata berupa tuturan dan tingkah laku subjek penelitian dan situasi di bidang penelitian, yang kita generalisasikan ke dalam model, konsep teoritis, prinsip, proporsi atau definisi. Analisis ini lebih menekankan pada aspek perilaku sosial dan komunikasi verbal yang sama menonjolnya (Arikunto, 2013, p. 107). Berpikir induktif adalah proses logis yang bergerak dari informasi empiris ke teori melalui observasi.

Analisis data menurut Miles dan Huberman dilakukan saat pengumpulan data berlangsung, dan setelah selesai pengumpulan data dalam periode tertentu. Aktivitas analisis data diawali dengan reduksi data, penyajian data, dan penarikan kesimpulan atau verifikasi (Sugiyono, 2019, p. 369)

a Pengurangan data

Reduksi didefinisikan sebagai proses pemilihan data mentah yang muncul dari catatan lapangan untuk disederhanakan, disarikan, ditransformasikan. Data juga dikurangi dengan ringkasan, pengkodean, tema penelusuran, pengelompokan, partisi, memo dll. Pengurangan ini berlanjut hingga laporan akhir disusun setelah penelitian lapangan.

b Penyajian data

Penyajian data menawarkan serangkaian informasi yang terorganisir yang memungkinkan pengambilan kesimpulan dan tindakan yang diambil.

c Penarikan atau verifikasi kesimpulan Ini dimulai dengan mencari makna, pola, penjelasan, kemungkinan konfigurasi, jalur sebab akibat, dan proposal di awal pengumpulan data. Kesimpulan "akhir" mungkin tidak akan tercapai sampai pengumpulan data berakhir, tergantung pada ukuran, pengkodean, penyimpanan dan metode yang digunakan. Kesimpulan selama kegiatan juga diverifikasi. Verifikasi juga dilakukan melalui review catatan lapangan.

Tabel 1

Latar belakang informan berdasarkan umur, pekerjaan dan pendidikan

\begin{tabular}{ccclc}
\hline No & Informan & Umur & Pekerjaan & $\begin{array}{c}\text { Pendidika } \\
\mathrm{n}\end{array}$ \\
\hline 1 & $\begin{array}{c}\text { Informan 1 } \\
\text { (Bunga) }\end{array}$ & $\begin{array}{c}55 \\
\text { tahun }\end{array}$ & Swasta & S2 \\
\hline 2 & $\begin{array}{c}\text { Informan 2 } \\
\text { (Mawar) }\end{array}$ & $\begin{array}{c}49 \\
\text { tahun }\end{array}$ & Staf Ahli & S2 \\
\hline 3 & $\begin{array}{c}\text { Informan 3 } \\
\text { (Melati) }\end{array}$ & $\begin{array}{c}46 \\
\text { tahun }\end{array}$ & $\begin{array}{c}\text { Wiraswast } \\
\text { a }\end{array}$ & S2 \\
\hline
\end{tabular}

Untuk menunjukkan bahwa penelitian dalam segala hal dapat dibenarkan, diperlukan teknik 
validitas data. Metode yang digunakan penulis untuk validitas data adalah:

Triangulasi metode untuk mencoba memeriksa validitas data atau validitas hasil penelitian. Metode triangulasi dapat digunakan untuk mencapai hal yang sama dengan menggunakan lebih dari satu teknologi pengumpulan data. Dalam hal ini, penyidik memeriksa data yang dipilih baik melalui wawancara maupun dokumen yang ada. Teknik pemeriksaan ini merupakan triangulasi dengan sumber data, yaitu membandingkan dan memeriksa tingkat kepercayaan informasi yang diperoleh melalui waktu yang berbeda dan metodologi dengan metode kualitatif yang digunakan, selain perbandingan pernyataan umum dengan pernyataan pribadi.

a Ketekunan observasi, bertujuan untuk menemukan elemen dan karakteristik dalam situasi yang sangat relevan dengan masalah atau isu yang dicari secara detail dan kemudian fokus pada subjek tersebut. Kemudian setiap kali me-review secara detail dan berulangulang sehingga semua informasi penelitian tersedia dan akhirnya dipahami dengan baik hasilnya.

b Diskusi dengan teman sejawat, peneliti mendiskusikan temuan penelitian dengan sesama anggota yang memiliki pengetahuan dan masalah dengan subjek yang diteliti. Peneliti membicarakan semua penelitian yang dilakukan peneliti. Hal tersebut akan memberikan masukan kepada peneliti dalam berdiskusi dengan rekan kerja sehingga peneliti pada akhirnya akan merasa percaya diri dengan hasil penelitiannya. Teknik ini berupa analisis terhadap hasil sementara atau hasil akhir yang diperoleh.

c Kecukupan referensi, kecukupan referensi berupa bahan rekaman yang digunakan sebagai tolok ukur dalam analisis data untuk pengujian. Cara lain untuk membandingkan kritik masih dapat digunakan jika perangkat elektronik tidak tersedia. Ada, misalnya, informasi yang tidak direncanakan lalu disimpan saat melakukan pengujian.

Menentukan dan merumuskan metode pengumpulan data (data primer dan sekunder). Awal pendataan adalah Oktober 2019 dan berlanjut hingga Januari 2020, ketika perempuan yang bercerai setuju. Awalnya peneliti meminta wawancara dengan surat dari Kalbis. Selain itu, peneliti diperbolehkan melakukan penelitian dengan informan. Untuk itu, peneliti mengirimkan email kepada informan untuk menjelaskan siapa peneliti tersebut dan tujuan serta pentingnya informasi yang dikumpulkan oleh informan tersebut. Peneliti meminta pertemuan formal di email untuk memperkenalkan diri dan memberikan informasi tambahan tentang penelitian. Secara keseluruhan, peneliti mewawancarai informan.

Terakhir, peneliti bertemu untuk mewawancarai informan secara formal dan orangorang yang menentukan di mana dan kapan wawancara dilakukan, biasanya setelah jam kerja. Setiap wawancara berlangsung antara 50 dan 75 menit, tatap muka dan secara langsung. Peneliti meminta data sekunder di akhir wawancara yang meliputi foto, buku teks, diagram, dan video (jika ada). Setelah menyelesaikan semua wawancara, peneliti memasuki analisis data dan mengumpulkan ratusan data.

\section{HASIL DAN PEMBAHASAN}

\section{Identitas Informan}

Gambaran karakteristik informan yang diteliti antara lain adalah nama, umur, pendidikan terakhir dan pekerjaan. Hasil yang diperoleh dalam penelitian ini didapat tiga orang informan. Dua orang informan bersedia untuk diwawancara dan satu informan menolak untuk dilakukan wawancara. Satu orang informan tersebut mengatakan bahwa ia malu dan takut diketahui identitasnya walaupun sudah mendapatkan jaminan kerahasiaan dari peneliti.

\section{Hasil Observasi}

Gambaran fisik informan pertama berupa kulit putih bersih terlihat dari wajah dan tangannya, badan padat, tinggi badan $\pm 161 \mathrm{~cm}$ dan berat badan $\pm 64 \mathrm{~kg}$. Cantik untuk ukuran seusia informan. Saat peneliti bertemu dengan informan, kesan pertama adalah ramah, tersenyum dan suka bercanda. Informan mengenakan pakaian muslimah yang sangat modis saat wawancara. Informan meminta bertemu di sebuah café di Jakarta Pusat. Kegiatan yang dilakukan informan adalah duduk sambil menyantap hidangan yang dipesan. Jawaban pertanyaan diselingi dengan candaan yang terkadang dia juga heran dengan kehidupan dia. Informan selalu melakukan kontak 
mata dengan peneliti selama wawancara. Semua pertanyaan yang diajukan dijawab dengan akurat dan jelas. Informan tampak beberapa kali memperbaiki posisi hijabnya yang terkadang turun dengan sesekali memperbaiki kacamata. Selama wawancara, informan sesekali tampak duduk bersandar dan sesekali condong ke depan.

Informan kedua memiliki ciri berkulit putih bersih, badan berisi, tinggi badan $\pm 155 \mathrm{~cm}$ dan berat badan $\pm 65 \mathrm{~kg}$. Peneliti melakukan wawancara di tempat makan pinggir jalan di Jakarta Selatan. Kesan pertama yang tampak saat bertemu dengan informan kedua adalah tomboi, menggunakan pakaian bergaya pria, dan gaya berjalan juga menyerupai pria. Informan mengenakan pakaian seragam kantor dengan celana cargo yang memiliki kantong banyak dan bersepatu boot pria. Kegiatan yang dilakukan informan adalah duduk sambil menyantap hidangan mie ayam dengan kelapa muda yang dipesan. Wawancara dilakukan setelah informan selesai makan. Agar suasana santai, informan menjawab pertanyaan diselingi dengan merokok dan mengingat-ingat kembali kehidupan dia. Informan sesekali juga memperbaiki letak kacamatanya namun tetap melakukan kontak mata dengan peneliti selama diwawancarai. Pertanyaan yang diajukan oleh peneliti dijawabnya dengan jelas dan detail.

\section{Hasil Wawancara}

Tabel 2

Data Informan tentang Panggung Depan (di kantor)

\begin{tabular}{cl}
$\begin{array}{c}\text { Inisial } \\
\text { Informan }\end{array}$ & \multicolumn{1}{c}{ Panggung Depan (di kantor) } \\
\hline 1 & $\begin{array}{l}\text { Gak ada yang tau lah klo di kantor, } \\
\text { biasa aja. }\end{array}$ \\
\hline 2 & $\begin{array}{l}7 \text { tahun jalan tanpa komitmen nikah. } \\
\text { Dari umur } 30 \text { tahun gue pacarin ... smp } \\
37 \text { tahun. }\end{array}$ \\
\hline
\end{tabular}

Tabel 3

Data Informan tentang Panggung Depan (di rumah)

\begin{tabular}{cc}
\hline $\begin{array}{c}\text { Inisial } \\
\text { Informan }\end{array}$ & Panggung Depan (di rumah) \\
\hline 1 & $\begin{array}{l}\text { Ooh sejak anakku nikah 2016, aku balik } \\
\text { lagi cm pacaran ama si O tapi ga ml di } \\
\text { rmh, pernah si pengen ml dirmh tapi }\end{array}$ \\
\hline
\end{tabular}

ga masuk2 haha keknya efek takut aja klu dirmh ya haha akhirnya Kita janjian ke Hotel bilangan Bekasi biar jauuh sekalian haha.

Sering aku ajak anak aku soale, klu yg dewasa malahan anak aku ga suka coz takut mamanya nikah haha. klu brondong Kan Aku GA mau nikah makanya anak aku anteng deh liatin mamanya ama brondong haha.

Punya kunci apartemen gue dia. Gue ngga ngiket dia. Kadang2 ngilang juga dia ... tp cerita dia Ig jln sm siapa. 2 Ujung2nya balik Ig ke gue. Kata dia klo pacaran sama yang seumuran atau dibawahnya gitu, dia bilang capek, posesiflah, terlalu banyak nuntutlah. Nah gue care banget soalnya.

Tabel 4

Data Informan tentang Panggung Belakang

\begin{tabular}{cl}
\hline $\begin{array}{c}\text { Inisial } \\
\text { Informan }\end{array}$ & \multicolumn{1}{c}{ Panggung Belakang } \\
\hline 1 & $\begin{array}{l}\text { Aku pilih pilih bgt soal cwo si } \\
\text { makanya nih ga merit merit uda 15 } \\
\text { taun haha. Keenakan ama } \\
\text { brondong juga keknya deh haha. }\end{array}$ \\
\hline 2 & $\begin{array}{l}\text { Masi blum siaplah, mending gw } \\
\text { sekolahin anak gw dulu aje, ama gw } \\
\text { sekolah lagi. }\end{array}$ \\
\hline
\end{tabular}

Tabel 5

Data Informan tentang Panggung Belakang (Role Distance)

\begin{tabular}{l}
\hline Inisial \\
Informan
\end{tabular}

Terakhir brondong aku 2018 ya si A yg beda umur 11 taun ama aku

1 haha. Nah 2019 ama si B dia umur 41 gegara dia aku rubah judul penelitian aku deh haha.

2 nikah. Nah pas single ya gpp dong. Just 4 sex ..no komitmen. 


\section{Tabel 6 \\ Data Informan tentang Panggung Belakang (Role Distance-PMS)}

\begin{tabular}{cc}
$\begin{array}{c}\text { Inisial } \\
\text { Informan }\end{array}$ & $\begin{array}{c}\text { Role Distance - Penyakit Menular } \\
\text { Seksual }\end{array}$ \\
\hline & lyalah tapi justru aku pilih pilih lah \\
& klu mau ml ama cwo kan biasanya \\
$\mathbf{1}$ & aku pacaran dlu jd tau siapa dia dll \\
& gtu. Alhamdulilah mrk bersih si \\
& haha jadi saat itu ya aku happy aja \\
& ngejalaninnya.
\end{tabular}

2 Mana enak pake kondom wkwkwk.

\section{Pembahasan}

Janda yang berhasil mencapai level seksual dan level terendah adalah ciuman bibir karena pelaku hubungan seksual di luar nikah mampu menangani dirinya sendiri dihadapan penonton sehingga sesuai dengan keinginan informan dan penonton. Para informan yang melakukan persetubuhan setiap saat harus melakukan yang terbaik dihadapan keluarga, teman dan masyarakat. Mereka sudah memiliki kemandirian finansial selama dan sebelum menjadi janda sehingga tidak bergantung pada laki-laki. Posisi dan status sebagai janda dapat dimainkan, sehingga semua berjalan sesuai harapan sebelumnya. Bagian pertunjukan Janda ini menunjukkan situasi terjadinya pertunjukkan. Domain wilayah yang menjadi situasi terjadinya pertunjukkan terbagi dalam beberapa bagian dan dijelaskan sebagai berikut:

\section{Depan Panggung atau Front Stage}

Visibilitas bagian depan selalu terlihat jelas oleh publik. Apa pun yang diungkapkan oleh pelaku seks dari area seperti itu juga terlihat. Karena itulah anggapan pertama bahwa pelaku seksual selalu terlihat di luar nikah. Mereka yang selalu menyimpan hal-hal ini untuk penonton yang menyukai. Di kawasan ini, banyak hal yang bisa dilakukan informan masih bisa dilihat secara spesifik, yang pertama adalah tempat. Arti yang melekat pada sejarah aktor untuk membantu penampilannya. Tempat tinggal informan memiliki pengaruh yang signifikan terhadap perilaku mereka. Situasi ini berada di lingkungan kerja dan keluarga (rumah).

Sebagai janda yang merupakan pelaku seksual di luar nikah, mereka adalah perempuan yang bekerja dan memiliki hubungan interpersonal yang kuat serta memiliki riwayat pengajar. Penempatan kerja informan satu diinstitusi pendidikan dan informan dua dilembaga pemerintahan, dan ketiganya di industri. Tempat kerja ini menjadikan janda-janda memiliki karir yang baik sehingga dipandang positif oleh publik.

Keluarga adalah tempat orang bersosialisasi, dan keluarga mempengaruhi pembentukannya. Informan memang dekat dengan lingkungan keluarga, namun tidak diketahui secara spesifik mengenai kondisi diri informan, terutama mengenai perilaku seksualnya. Ternyata dari pengakuan mereka, aktor tersebut tampaknya pantas mendapatkan kepercayaan pada keluarga. Selain itu, teman dekat mereka tidak berani mengajaknya bersama keluarga. Di rumah, bisnis keluarga tetap berjalan seperti biasa dan memberikan kesan bahwa seks tidak mempengaruhi kehidupan mereka.

Perilaku informan, terutama perilaku seksual, masih dapat dikontrol dalam keluarga yang biasanya memegang nilai dan standar sosial. Keluarga juga merupakan tempat penting untuk transfer budaya, meskipun hanya tersedia di lingkungan keluarga, untuk melindungi perilaku anak-anaknya. Setiap informan memiliki kebebasan finansial untuk menghidupi dirinya sendiri dan mengharumkan nama keluarganya.

Saat memilih peran yang kemudian meningkatkan representasi kolektif di balik pemilu yang diambil secara sadar, mereka membutuhkan alasan. Penjelasan ketidakpuasan penonton terhadap perilaku di belakang panggung adalah melihat penampilan di dahi yang sesuai dengan standar masyarakat. Aktor sadar bahwa budaya tidak mengakui aktivitas seksual di luar pernikahan. Selain mereka, beberapa orang dicap sebagai informasi yang baik dan superior di depan, sehingga penonton tidak ingin melihat tindakan yang tidak pantas. Masyarakat harus memahami semua yang dimiliki informan sehingga ketika melihat front stage mereka akan menilai informan sebagai person di masyarakat. Orang-orang hebat telah diperoleh sejauh ini dari keluarga informan karena mereka dapat menangani pekerjaan. Para pelanggar memberikan umpan balik dan pemahaman yang jelas dan konstruktif dalam komunitas keluarga. Ini merepresentasikan prioritasnya dan mendorongnya untuk memilih front hand, bukan membangun image yang sempurna pada presentasi tahap pertama, seperti 
yang dikatakan Goffman (Ritzer \& Goodman, 2005 , p. 400) sehingga mereka merasa harus meliput hal yang berbeda. Mereka melakukannya di film.

Seringkali kita cenderung memilih tindakan yang sesuai dengan minat dan aspirasi serta aspirasi orang lain yang sejalan dengan nilai dan norma, peran dan aktivitas informan di tempat kerja. Informan cenderung melakukan tindakan yang layak dan tidak jujur di tempat kerja, tetapi mereka adalah pemimpin perilaku seksual yang sebenarnya di rumah. Selain itu, teman-teman Anda di luar keluarga tidak membicarakan aktivitas seksual mereka, tetapi berbeda untuk teman serumah Anda. Mereka cuek, ternyata mereka satu komunitas, komunitas yang mencoba dan menormalisasi informan untuk membuat standar baru menurut kelompoknya. Namun, menurut undang-undang, beberapa informan berperilaku karena rumah tidak aman, tetapi mereka juga melakukan hal-hal di luar rumah.

Yang kedua adalah wajah individu, wajah khusus adalah hal-hal yang harus diikuti oleh seorang aktor, terutama yang berkaitan dengan dirinya untuk menawarkan keunikannya lebih dari yang lain. Di mana aktor melakukannya, wajah orang itu selalu terbawa. Presentasi dan gaya dapat dibagi menjadi dua dalam hal ini. Kepribadian berarti ciri-ciri tubuh bersifat visual. Informasinya tidak unik, dan sisanya, detailnya, sama familiarnya.

Fase depan yang meliputi setting ditunjukkan oleh corak atau penampilan informan dengan atribut keagamaannya. Bahkan lebih setia kepada agamanya. Simbol yang digunakan dan penampilan yang disajikan bersifat religius hanya jika informan sadar bahwa perilaku yang dipilih dan dilakukan melanggar norma agama. Goffman membandingkan dunia dengan drama di mana orang menjadi aktor yang mewakili gulungan dan masyarakat. tunduk pada pembentukan aturan standar rasa realitas dengan orang lain untuk menjamin citra orang lain (Giddens et al., 2005, p. 124). Dengan mengenakan hijab, para informan telah memilih untuk menjadi lebih religius kepada umat Islam, dan aktor lain selalu berusaha untuk mendapatkan tampilan yang bagus yang mencerminkan ketaatan beragama mereka. Semuanya juga mencerminkan gayanya dengan cara yang sempurna dan ramah. Tata krama dan kesopanan Goffman merupakan atribut fisik yang bermakna secara detail, yaitu sangat sedikit detail, harta benda atau aktivitas yang tidak digunakan dalam kehidupan teater ini. Pakaian yang kita kenakan, rumah tempat kita tinggal, bagaimana kita menyesuaikan rumah kita, bagaimana kita berjalan dan berbicara, bagaimana kita melakukannya dan bagaimana kita menghabiskan waktu luang kita adalah semua hal yang diketahui publik tentang kita. Kita sedang membicarakan orang lain (Jones, 2009, p. 145).

Orang yang diwawancarai yang memainkan peran penting dalam situasi rumah ternyata mulai bertingkah seperti di tempat lain tetapi ingin menunjukkan perilaku lain, yang tidak mereka ketahui di luar rumah. Cara lawan jenis membeli rumah ini tidaklah aneh. Karena adegan semacam ini masih diawasi di sekitarnya oleh ketua RT, karena memiliki kebebasan finansial, di hotel dan apartemen yang dipakai bersama, mereka melakukan hubungan pra nikah.

\section{Mengolah Kesan Diri}

Kontrol citra diri adalah kombinasi dari beberapa ukuran yang berkontribusi pada gaya hidup informan. Manajemen interpretasi yang diinginkan telah berjalan dengan baik karena informan tidak memiliki masalah dengan perilaku yang sebenarnya. Semua komponen membantu produksi pertunjukan dalam hal ini. Dalam mengolah pertunjukan, ia melakukan beberapa hal, diantaranya berperilaku lebih religius dan berinteraksi sosial asosiatif.

Mengikuti iman dan penampilan mereka sebagaimana diajarkan oleh komunitas mereka, mereka memiliki ilusi bahwa mereka lebih saleh. Ngomong-ngomong, dari data mereka yang beragama Islam, mereka menjalankan tugas-tugas agama dalam mengajar, termasuk sholat, puasa, dan pengajian yang secara fisik wanita mengenakan hijab pada penampilan luarnya. Namun, sebagai anggota tetap dan berkelanjutan, sejauh ini tidak ada informan yang berpartisipasi dalam organisasi keagamaan.

Informan memiliki kemitraan dan kerjasama yang kuat dengan publik. Interaksi yang terjadi merupakan interaksi berdasarkan keinginan informan. Mereka tidak ingin proses bisnis disosiatif yang mereka khawatirkan merugikan. Banyak juga yang cenderung terlibat politik, sehingga banyak orang merangkul kehadirannya tanpa didengarkan. Interaksi antar mitra 
diutamakan agar impresi dapat diolah dengan tepat, sesuai keinginan informan dan lingkungan di mana masyarakat terlibat.

Pemantauan persepsi responden dilakukan dengan sangat bersih sehingga khalayak akan cenderung meyakini apa yang disampaikan sesuai dengan tujuannya. Informan mengelola kesan dengan menyajikan secara fisik dan secara kompartemen lebih banyak item religius yang berusaha memenuhi ajaran spiritual mereka. Terkadang informan telah hidup dalam lingkungan religius sejak kecil, baik sekolah, komunitas, atau keluarga, dan harus sesuai dengan nilai-nilai yang selama ini mereka pelajari untuk mengatur kesankesan mereka. Informan juga berupaya memanipulasi pengalaman melalui interaksi yang berkontribusi pada kerjasama dan pencegahan konflik. Informan menampilkan perilaku yang baik sehingga tidak banyak yang tahu tentang perilaku aslinya. Informan membangun hubungan yang kuat sehingga audiens mendukung dan menghasilkan hal yang baik. Hadirin bekerjasama dengan informan dan mereka tidak menyadarinya. Dalam Ritzer \& Goodman (2005, p. 300), Goffman memiliki banyak teknik untuk memahami pengendalian impresi, salah satunya adalah berbagai pendekatan termasuk tindakan yang bertujuan untuk membangkitkan loyalitas yang dramatis. Informan dapat memilih audiens yang tepat untuk menunjukkan apa yang mereka maksud. Para informan seringkali melakukannya untuk kepentingannya sendiri, bahkan dalam pengelolaan impresi, tanpa melihat kepentingan orang lain. Misalnya, ketika berada di lingkungan keluarga, apa yang terjadi pada salah satu informan cenderung diam, tidak banyak berinteraksi dengan anggota keluarga, dan tidak pernah membagikan detail pribadinya. Ada yang selalu tidak bisa tersentuh oleh ranah pribadinya sehingga saat berada di antara penonton mereka selalu bersembunyi. Manning (1992:44) mengkaji hal ini dari segi pandangan sifat sinis, yaitu pernyataan umum tentang ekspresi diri dalam kehidupan manusia, baik secara individu maupun kelompok mengikuti tujuan masing-masing dan secara sinis mengabaikan kepentingan orang lain. Single di sini dianggap sebagai rangkaian karya sinis dan manipulasi bertopeng (Ritzer \& Goodman, 2005, p. 302).

Dunia ketiga, zona terluar, dikenal sebagai area residual, muncul ketika memikirkan tentang dramaturgi (Ritzer \& Goodman, 2005, p. 301). Bagian depan atau belakang panggung pementasan informan tidak termasuk dalam area ini melainkan area di luar pertunjukan. Informan memproyeksikan diri ke khalayak, keluarga (rumah), dan tempat kerja yang berbeda, mengikuti tujuan mereka. Di panggung depan, informan menciptakan kepribadian yang benarbenar optimis untuk penonton. Bahkan penonton keluarga (di rumah) tidak tahu persis bagaimana perilaku informan tersebut. Pada saat yang sama, dia berada di luar rumahnya atau bersama musuh. Auditor keluarga dan rekan keluarga yang dapat dipercaya, termasuk anak dari informan itu sendiri, menyadari hak informan untuk merujuk pada istri, ibu, atau pendamping lainnya. Kami juga dapat merumuskan apa yang kami lakukan, termasuk perilaku seksual mereka, ketika informan sedang bersama pasangan atau kerabat dari jenis kelamin mereka yang lain.

Tempat istirahat ini atau bagian luar depan dan belakang panggung informan adalah alasan utama menyimpan rahasia. Seperti dijelaskan dalam J. Indarto, bidang ketiga adalah penciptaan operasi semu tersebut (Indarto, 1996). Dalam lingkungan ini, ada hubungan antara informan sebagai pelaku. Ketika bagian ini terungkap, akan sangat merugikan identitas informan jika audiens yang diminta mencapai belakang panggung, karena mereka menginginkan apresiasi dan persetujuan publik Goffman terhadap lingkungan tempat orang-orang tampil. mendefinisikan keadaan tertentu, dengan fokus khusus pada dukungan sosial perusahaan untuk konsepsinya sendiri (Salim, 2008).

\section{Panggung Belakang atau Back stage}

\section{Role Distance}

Dengan memisahkan diri dari perannya, maka terjadi perbedaan peran yang dimainkan oleh informan. Mereka tampak memiliki peran ganda, yaitu melakukan aktivitas seksual di luar nikah dan bertindak sebagai orang yang sesuai dengan nilai dan standar. Selama ini informan merasa bersalah, terutama dengan Tuhan. Sepertinya mereka menarik diri dari posisi. Karena Anda tahu nilai dan standar masyarakat sekitar adalah violet, penting juga bagi Anda untuk menunjukkan bahwa Anda tidak ingin memainkan peran Anda yang sebenarnya. Jarak peran yang biasanya dimainkan informan memiliki fungsi peran.

Karakter Goffman menitikberatkan pada sisi penampilan dari dramaturgi yang merupakan aliran interaksi simbolik dan dihubungkan dengan 
makna dari sesuatu, sehingga hidup ibarat bermain dengan aktor dengan peran yang beragam. Ini memiliki beberapa arti, dan berbagai bentuk peran dan tindakan baik di panggung maupun di belakang panggung dan pengalaman sosial memiliki peran dalam memilih posisi yang dilakukannya. Aktor yang bertindak disengaja jika perilakunya merupakan pilihan yang diinterpretasikan oleh penonton melalui simbolsimbol yang dikonstruksi aktor tersebut pada sepenggal pameran.

Terpisah dari peran informan hingga saat ini, tampaknya kita meyakini adanya pembagian fungsi yang membuat posisinya sulit selama ini. Selain itu, informan memahami dan mengakui bahwa perilaku yang bertentangan dengan standar dan norma masyarakat adalah aktivitas seksual di luar nikah. Memang, setiap orang takut dengan standar agama dan ingin menunjukkan bahwa mereka tidak benar-benar menginginkan posisi itu. Dengan peran yang dimainkan oleh mereka bahkan keluarga dan teman-teman, mereka cenderung merasa sangat bersalah terhadap Tuhan. Ketidaknyamanan dengan tindakan yang berbenturan kemudian merasa tidak enak dan menjadi kurang tertarik pada masalah orang lain, terutama terkait perilaku kencan mereka. Aktor itu terus memainkan peran tersebut tetapi tidak sepenuhnya tenggelam dalam perilaku seksual normal. Ada alasan untuk melakukan bagian itu. Mereka juga masih merasa bersalah dan berdosa. Adapun dalam teori dramaturgi, Goffman berpendapat bahwa hanya sedikit yang memainkan peran unik karena banyaknya peran yang mereka mainkan. Jarak Peran menunjukkan bagaimana kepribadian dan peran yang diharapkan ia mainkan secara terpisah satu sama lain (Ritzer \& Goodman, 2005, p. 302). Pembagian peran informan yang merasai benturan merupakan perilaku yang melanggar nilai dan standar yang tidak boleh dilakukan sedemikian rupa sehingga informan merasa bersalah dan berdosa kepada Tuhannya serta merasa menipu sanak keluarganya. Dia juga tidak peduli dengan keluarganya (rumah), bahkan jika dia ingin menunjukkan bahwa dia senang dengan penonton dan bahwa perilakunya tidak menimbulkan masalah.

\section{Mistifikasi}

Informan juga mengisolasi penonton satu sama lain. Hal ini telah dihadirkan sedemikian rupa sehingga penonton tidak dapat lebih mengenalnya secara lebih mendalam yaitu melalui beberapa pertanyaan. Para aktor memainkan peran penting dengan menjaga jarak agar tidak terus mempertahankan reputasi mereka. Penonton selalu memetik sesuatu yang dimainkan informan tanpa mengetahui sebenarnya di balik posisinya. Namun, jika mereka secara seksual dan teman kencan terkunci, dalam keluarga, kenalan, atau budaya, informan tidak menjauh dari audiens mereka. Mereka memiliki banyak teman, sehingga hubungan dan komunikasi sosial mereka tidak tertutup. Beberapa informan suka menjauhkan diri untuk membuat audiens menolak, padahal mereka memiliki banyak teman dan juga mencintai keluarga dan masyarakat. Namun, beberapa hal perlu ditutupi. Para informan seringkali lebih terbuka dan dekat dengan pasangannya. Meski begitu, hampir semua orang memisahkan diri dari keterbukaan seksual, hanya keterbukaan dalam hal-hal tertentu, untuk aktivitas seksual yang dimasukkan ke dalam domainnya.

Informan tidak mengisolasi diri dari kolega, percaya bahwa mereka memiliki banyak teman dan dekat dengan komunitas keluarga. Meskipun demikian, narasumber tidak transparan tentang usia mereka. Namun, meskipun informan transparan dan tidak ragu-ragu untuk memberi tahu teman sebayanya, mereka adalah pelaku pelecehan seksual dan mengungkapkannya kepada orang lain dalam kelompok sebaya mereka. Mereka sangat tertutup bagi orang lain. Semua informan mengetahui perilaku seksual mereka tentang keluarga dari data tersebut. Goffman mengatakan mistifikasi adalah praktik yang dilakukan oleh para aktor. Para pemain sering salah merepresentasikan penampilan mereka dengan mengurangi hubungan mereka dengan penonton (Ritzer \& Goodman, 2005, p. 300). Informan cenderung mengisolasi diri dari masyarakat untuk memastikan khalayak tidak memperluas wilayahnya. Kami tetap berkomunikasi dengan baik meskipun mereka tidak mengunci diri. Ketahuilah audiensnya dan dekatlah.

Terlepas dari apapun alasannya menurut psikolog keluarga dari Universitas Indonesia, Dr. 
Rose Mini Agoes Salim, M.Psi., ada beberapa hal yang membuat seorang perempuan akhirnya lebih betah menjanda. "Biasanya yang bikin perempuan lebih memilih menjanda karena sudah malas beradaptasi lagi dan memulai semuanya dari awal. Apalagi kalau misalnya kariernya juga sudah mulai menanjak, banyak yang memilih fokus pada karier saja. Mereka sudah merasakan kebebasan dengan hilangnya tanggungjawab sebagai seorang istri," tutur Rosmini, atau yang juga akrab dipanggil dengan sebutan Bunda Romi(Widiyarti, 2017).

\section{SIMPULAN}

Berdasarkan ringkasan data yang dikumpulkan dan interpretasi dari penelitian bingkai kehidupan janda meneropong dari kacamata dramaturgi bisa disimpulkan bahwa para janda memang mesra dengan lawan jenis, mulai dari tahap berpegangan tangan hingga aktivitas seksual. Namun, Anda dapat mengembangkan pengalaman dan menjaga privasi di ruang publik. Karya ini menganalisis bagaimana informan dapat menciptakan pemahaman pribadi tentang teori dramaturgi Erving Goffman. Ada tempat di mana informan melakukan drama yaitu front stage melibatkan lingkungan dan sisi pribadi. Informan memiliki sikap dan perilaku yang berbeda untuk lingkungan keluarga (rumah) dan pekerjaan. Dia memiliki penampilan yang baik dan integritas dalam bekerja di keluarganya (rumah). Wajah pribadi, termasuk kepribadian informan, juga sangat cantik dan lebih bersahabat, menekankan pada kualitas spiritual dan keindahan alam sehingga penonton dapat melihat hal-hal yang baik.

Jarak sosial yang dibangun informan memang membingungkan, tetapi mereka tidak terlalu jauh dari audiensnya. Anda punya banyak teman dan hubungan dekat dengan audiens Anda. Perlu dicatat bahwa informan cenderung mengisolasi diri dari publik dalam hal aktivitas seksualnya; mereka memilih untuk tidak mengungkapkan ini karena mereka takut ditanyai tentang masalah mereka. Beberapa belahan dunia dari tampilan depan adalah dunia luar yang tidak menyaksikan penampilan: depan atau belakang dan dunia ke-3 atau dunia luar. Dunia ketiga telah dikolaborasikan dengan informan utama oleh masyarakat dunia ketiga karena perilaku informan utama adalah menjaga kerahasiaan.

Hal ini bermanfaat untuk menangani pandangan informan yaitu mengolah informasi sehingga sesuai dengan kebutuhannya. Kepada delapan informan tersebut, dua hal yang mereka lakukan untuk mengambil pengalaman adalah memperhatikan, yaitu lebih aktif secara sosial, bertindak sesuai dengan nilai-nilai yang dimilikinya. Para aktor kemudian menciptakan koneksi asosiatif dengan penonton - interaksi yang mengarah pada kerja sama dan pencegahan konflik, untuk memastikan pertunjukan yang lancar. Peran jarak menyebabkan rasa bersalah dan dosa terhadap keluarga, teman, dan Tuhan pada khususnya. Informan dipisahkan dari perannya. Untuk menunjukkan, misalnya, bahwa mereka masih memikirkan kesesuaian perilaku, nilai, dan standar seksual mereka. Selama ini mereka belum pernah terlibat di luar nikah sebagai aktor seksual bahkan ketika informan mengatakan bahwa mereka tidak mempersoalkan aktivitas seksualnya dalam komunitas yang sama, yaitu lingkungan keluarga (rumah).

\section{DAFTAR PUSTAKA}

Arikunto, S. (2013). Prosedur Penelitian. Rineka Cipta.

Bungin, B. (2003). Pornomedia: Konstruksi Sosial Teknologi Telematika \& Perayaan Seks Di Media Massa. Kencana Prenada Media Group.

Estriana, V., \& Wahid, U. (2019). Erving Goffman's Approach in Perspective and Selfpresentation of Transgender in Tambun Bekasi. International Journal of Multidisciplinary Research and Publications,2(3),71-77.

https://www.researchgate.net/profile/Umaimah _Wahid/publication/342397925_Erving_Goffma n's_Approach_in_Perspective_and_Self_presentation_of_Transgender_in_Tambun_Bek asi/links/5ef27e3aa6fdcc158d2460d1/ErvingGoffmans-Approach-in-Perspective-and-Selfpresentation-of-Transgender-in-TambunBekasi.pdf

Giddens, A., Bell, D., \& Forse, M. (2005). Sosiologi: sejarah dan berbagai pemikirannya. Kreasi Wacana.

Goffman, E. (1959). The Presentation of Self in Everyday Life. Anchor Books.

Hersavira, D. (2019). Dramaturgi Relasi Dokter Dan Pasien Di Rumah Sakit Umum Daerah Dr.Zainoel Abidin Banda Aceh. 
http://repository.umsu.ac.id/bitstream/1234567 89/5236/1/TESIS DARA HERSAVIRA.pdf

Indarto, J. (1996). Prinsip-Prinsip Dramaturgi. Jurnal Dinamika, VIII(1).

Jones, P. (2009). Pengantar Teori-Teori Sosial. Yayasan Obor Indonesia.

Koentjaraningrat. (1991). Metode Penelitian Masyarakat. Universitas Indonesia (UI-Press).

Moleong, L. J. (2008). Metodologi Penelitian Kualitatif (Revisi). Remaja Rosdakarya.

Mulyana, D. (2006). Metode Penelitian Kualitatif. Remaja Rosdakarya.

Nugraha, A. (2005). Pengembangan Pembelajaran Sains Pada Anak Usia Dini. Depdiknas.

Paramithasari, N., \& Kartika, R. (2017). Lima Kualitas Sikap Komunikasi Antar Pribadi oleh Unit Customer Complaint Handling PT BNI Life Insurance. CoverAge: Journal of Strategic Communication, 8(1), 1-11. http://journal.univpancasila.ac.id/index.php/co verage/article/view/1117

Putranto, A., \& Delliana, S. (2019). Representation of Symbolic Violenceln Women's Body In Online Media(Case Study at Tribunnews inCovering the Case of OnlineProstitution by Artist Vanessa Angel). Kanal: Jurnal Ilmu Komunikasi, 7(2), 41-48. https://journal.umsida.ac.id/index.php/kanal/a rticle/view/46/29

Ritzer, G., \& Goodman, D. J. (2005). Teori sosiologi modern. Prenada Media Group.

Salim, A. (2008). Pengantar Sosiologi Mikro. Pustaka Pelajar.

Salisa, A. (2010). Perilaku Seks Pranikah Di Kalangan Remaja (Studi Deskriptif Kualitatif Tentang Perilaku Seks Pranikah Di Kalangan Remaja Kota Surakarta). https://core.ac.uk/download/pdf/16508756.pd $f$

Sugiyono. (2019). Metode Penelitian dan Pengembangan: Research and Development. Alfabeta.

Utami, S. (2018). Kuliner Sebagai Identitas Budaya: Perspektif Komunikasi Lintas Budaya. CoverAge: Journal of Strategic Communication, $8(2)$, 36-44. https://doi.org/https://doi.org/10.35814/cover age.v8i2.588

Widiyarti, Y. (2017). Alasan Perempuan Memilih Menjanda dan Malas Menikah Lagi. Tempo.Co. https://cantik.tempo.co/read/1020548/alasanperempuan-memilih-menjanda-dan-malasmenikah-lagi 